\title{
Diving investigations on biodeterioration by sea-urchins in the rocky sublittoral of Helgoland
}

\author{
W. E. Krumbein ${ }^{1} \&$ J. N. C. Van der Pers ${ }^{2}$ \\ ${ }^{1}$ Biologische Anstalt Helgoland (Meeresstation); Helgoland, \\ Federal Republic of Germany \\ and \\ ${ }^{2}$ Geologisch Instituut; Groningen, The Netherlands
}

\begin{abstract}
KURZFASSUNG: Tauchuntersuchungen zur Biodeterioration des Felslitorals von Helgoland durch Seeigel. Die Biodegradation von Unterwasseraufschlüssen von Buntsandstein, Muschelkalk und Kreide wurde mittels Tauchuntersuchungen und anschließender Laborexperimente untersucht. Die Biodeterioration wird durch die intensive Wechselbeziehung zwischen individuenreichen Populationen des Polychaeten Polydora ciliata (J.) und des Seeigels Echintus esculentus (L.) verursacht. $P$. ciliata ist der wichtigste felsbohrende Organismus des Sublitorals zwischen 8 und $20 \mathrm{~m}$ Wassertiefe. Er bohrt in (kalkreichen) Sandsteinen des Mittleren Buntsandsteins, in Kalken und Mergeln des Muschelkalks und der Kreide. E. esculentus weidet überwiegend auf den Teppichen von $P$. ciliata, indem er zunächst die Oberfläche von den nicht so nährstoffreichen Schornsteinen säubert und dann das Gestein mit den darin befindlichen Würmern abraspelt. Er gräbt bis zur Tiefe der meisten Bohrlöcher hinab und läßt nur extrem tief eingegrabene Würmer überleben, in deren Nähe sich dann neue Larven festsetzen und neue Kolonien beginnen. Die Populationsdichte von E. esculentus wurde mit ca. 1-7 Individuen pro $\mathrm{m}^{2}$ ermittelt. Berechnungen der Bioerosionsrate durch die „Polydora ciliataEchinus esculentus-Gemeinschaft" erreichten je nach verwendeter Annäherung bis zu $1 \mathrm{~m} / \mathrm{Jahr}-$ hundert. Dies ist gemessen an anderen Beridhten eine überaus hohe Biodeterioration für das Sublitoral. Die Okologie von E. esculentus bei Helgoland unterscheidet sich wesentlich von der in anderen Küstengebieten mit Felslitoral. Auf Grund des relativ jungen Ursprungs der Insel (ca. 4000 Jahre vor Chr.), der äußerst weichen Gesteine und der extrem hohen Biodeterioration wird angenommen, daß die "Polydora ciliata-Ecbinus esculentus-Gemeinschaft" ihr eigenes Substrat sehr schnell zerstört und sandige Ablagerungen allmählich das Felslitoral im sublitoralen Bereich ersetzen werden.
\end{abstract}

\section{INTRODUCTION}

Three common species of sea-urchins occur in the German Bight: Echinus esculentus, Psammechinus miliaris and Echinus acutus. Echinus acutus prefers deeper sandy bottoms, Psammechinus miliaris occurs mainly in tidal channels and some gullies of Wadden Sea, and E. esculentus is reported from the rocky sublittoral of the North Sea island of Helgoland, as well as from the pleistocene moraines and the oyster banks of the Helgoland region. Few specimens have been found at Borkum reef. E. esculentus 
usually inhabits rocky substrates in water depths between 5 and $40 \mathrm{~m}$. It has also been reported for environments as deep as $1200 \mathrm{~m}$.

A dense population of Psammechinus miliaris was found on the sandy bottoms of the Helgoland harbour. Few individuals intermingle with the abundant Echinus esculentus population on the rocky grounds around Helgoland. E. esculentus increases in numbers with increasing depth. The first specimens have been observed at water depths between 4 and $8 \mathrm{~m}$, where the population density of the alga Laminaria byperborea decreases (LÜNING 1970). At the same depth carpets of the boring polychaete Polydora ciliata become more abundant.

ORTON (1930) reports Echinus esculentus also from shallow water beginning with low water spring tide level (MLWS). Ecological studies on E. esculentus are generally scarce and completely lacking for the Helgoland rocky bottoms. This is due to the complicated methods required for the investigation of the sublittoral zone. The first detailed investigation of the ecology and behaviour of $E$. esculentus by modern SCUBA-diving methods has been done by FORSTER $(1958,1959)$ on the English coasts.

During diving investigations of the geology and tectonic structure of Helgoland and of the distribution of Polydora ciliata and other rock-boring organisms on different substrates and in different environments a close relationship between the activity of $P$. ciliata, E. esculentus and the biodeterioration of the rocky bottoms was observed.

Literature on the geology of Helgoland has been summarized by PRA'TJE (1923), WURSTER (1962) and HaRTUNG (1970). They make no reference to underwater erosion of the rocky substrates of Helgoland as being due to any other reason than wave action. Terraces found at 13-17 and 18-25 m water depth probably indicate older shorelines due to the post-glacial sea-level rises during the "Atlantic" transgression.

The Triassic sandstones of the main island are exposed in the intertidal zone and extend in the northeastern and southwestern parts of the Helgoland structure to water depths of approximately $20 \mathrm{~m}$. The southwestern terrace is characterized by a complicated fault system of a vertical separation of $300-500 \mathrm{~m}$. This permits the study of Echinus esculentus populations at the same water depth of $8-25 \mathrm{~m}$ on various different bedrocks. These include underwater cliffs and flat bottoms of Lower Triassic sandstones and marls (Buntsandstein), Middle Triassic limestones and marls (Muschelkalk) and Cretaceous clays, marls and limestones including large areas of soft chalk with embedded layers of flint.

It is the aim of this paper to describe the contribution of the Polydora ciliata and Echinus esculentus community to the underwater erosion of the various rock types of Helgoland. The terms bioerosion as defined by Neumann (1966) and biodeterioration (KRUMBEIN 1972) are used simultaneously though slight differences exist inasmuch as the term biodeterioration includes fouling.

\section{RESULTS}

\section{Underwater observations}

Populations of Echinus esculentus have been studied at the following places (Fig. 1): (1) Hog Stean and other isolated rocks of Cretaceous chalk protruding from 


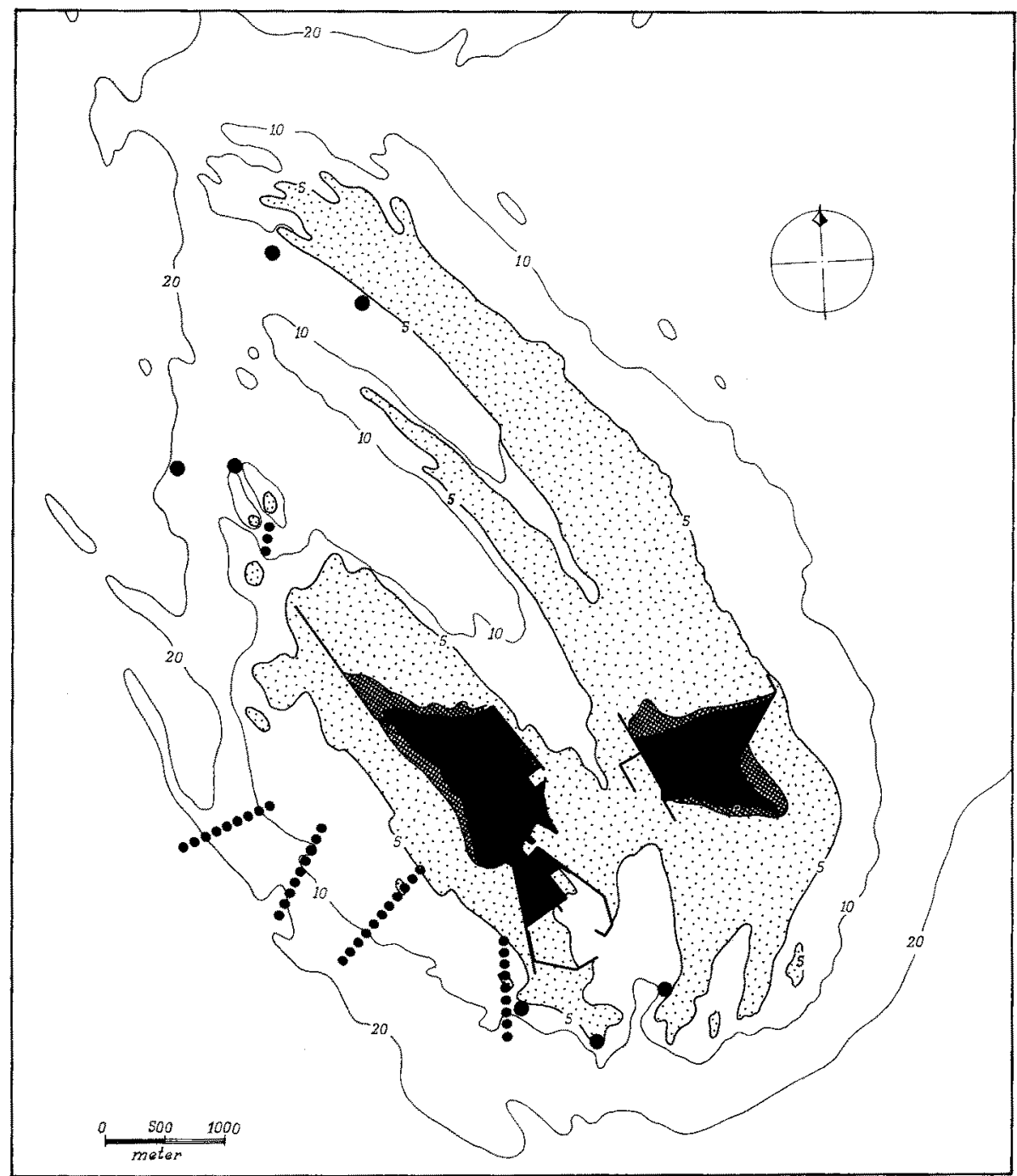

Fig. 1: Map of the Helgoland area (salt dome structure) with the main underwater observation sites. Bladk : Land; hatched : intertidal area; dotted : upper sublittoral. Main distribution of the Polydora ciliata-Echinus esculentus community between 5 and $20 \mathrm{~m}$ water depth

the coarse sandy bottoms south of Helgoland; (2) On Lower Triassic sandstones and marls, isolated boulders, Middle Triassic limestones and marls and Cretaceous chalk along 4 transects southwest of Helgoland (Fig. 1); (3) On the smooth substrate of Cretaceous chalk at the location of "Repulse Grund" in the northwestern part of the structure. The population density of $E$. esculentus according to our observations is governed by the following factors: (1) Food supply, (2) water movement and (3) 


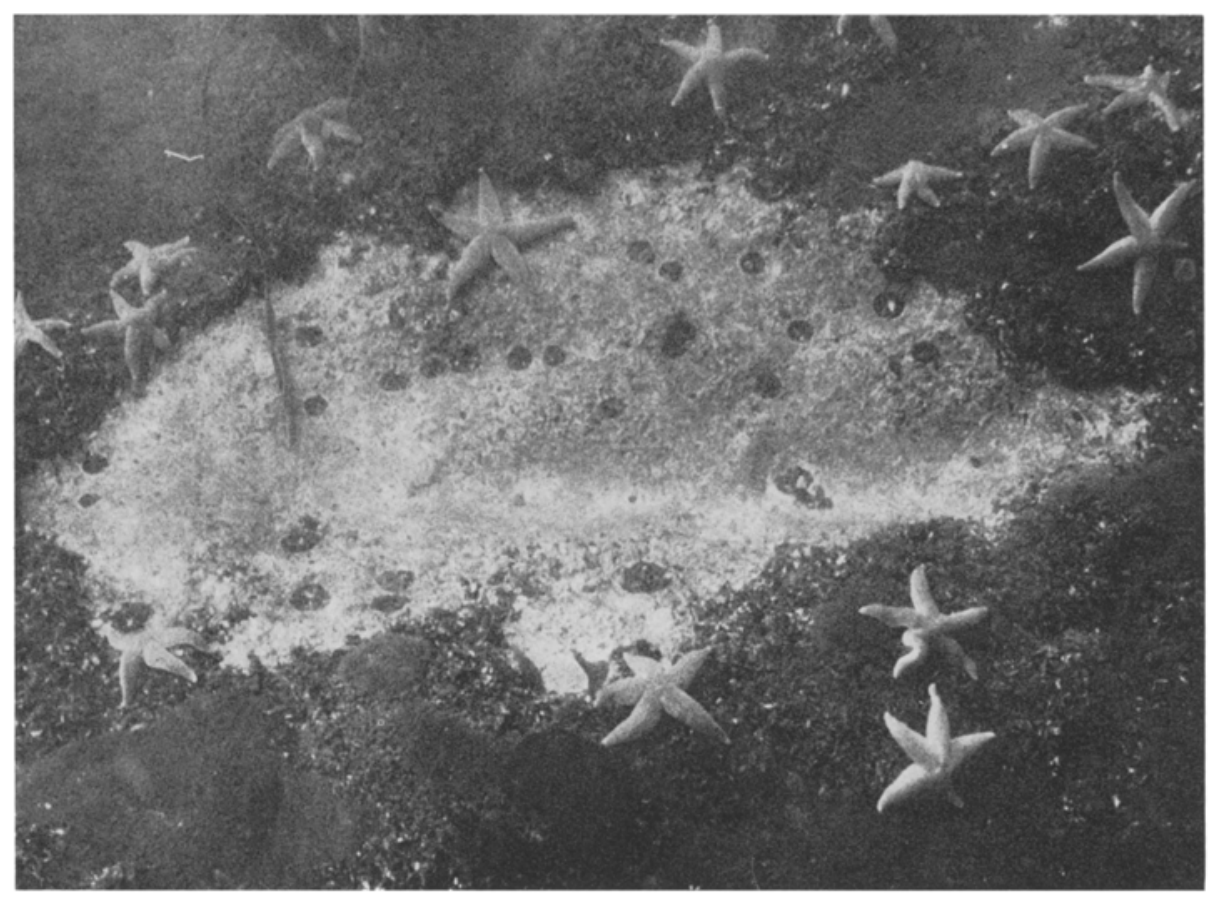

Fig. 2: Underwater photograph of an area cleaned and polished by tidal currents between the cliffs north of the Helgoland dune. The surroundings are populated by dense Mytilus edulis populations and Polydora ciliata carpets. On the clean area only boring molluscs can settle

competition with Laminaria sp. (Jones \& KaIN 1967). At Helgoland the main prey of E. esculentus is Polydora ciliata. The distribution of both organisms is ruled by water depth and water movement. Whereas $P$. ciliata occurs already in the intertidal zone, $E$. esculentus is very rarely observed above MLWS. ORTON (1930) described E. esculentus in shallow water during extremely calm conditions where no turbulence or tidal rigs occur and where it finds suitable rocky bottom.

At Helgoland Echinus esculentus increases considerably in numbers wherever Laminaria byperborea is decreasing and thus leaving vacant space for the borings and chimneys of Polydora ciliata. At this water depth $(8-10 \mathrm{~m})$ E. esculentus feeds frequently on $P$. ciliata, encrusting algae, colonies of Bryozoa and phylloids of Laminaria which fall to the bottom. With decreasing water movement and algal cover the importance of $P$. ciliata as bottom dweller increases and with it the population density of $E$. esculentus. Wherever tidal channels and obstacles create higher water velocities even at greater depths, $P$. ciliata does not form carpets. At these places only boring molluscs are capable of settling. They protrude from clear white surfaces polished by sand carried along with the current. At these locations $E$. esculentus does not occur, whereas $P$. ciliata has only been observed when it could settle in the empty bore-holes of molluscs (mainly produced by Barnea candida, Zirfaea crispata and Petricola pholadiformis). 


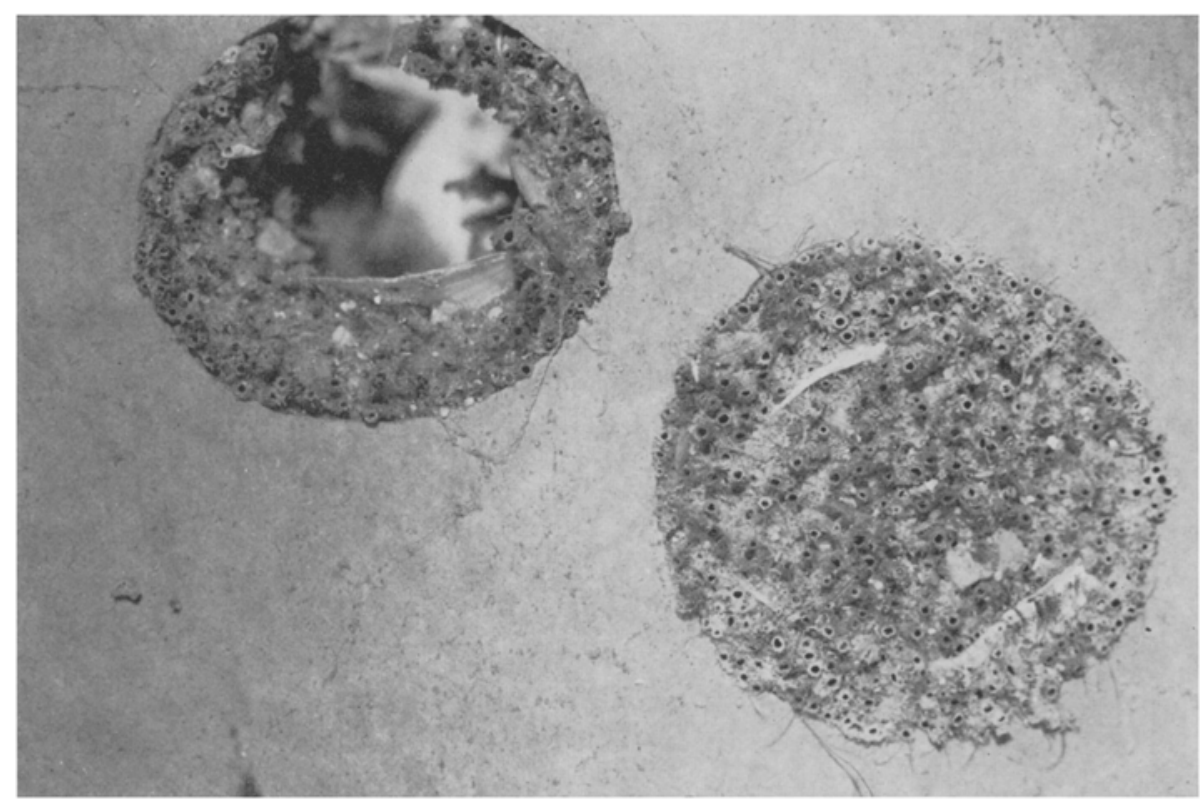

Fig. 3: Example of settling behaviour of Polydora ciliata at places where, due to high water movement, $P$. ciliata can only settle in the empty holes of boring molluscs (see text)

The worm then bores parallel to the rock strata while the chimneys stand at right angles to the worm's bore-hole and fill up the empty mollusc burrow (Figs. 2 and 3).

The current velocity does not permit Polydora ciliata to elevate its chimneys above the walls of the molluse bore-hole (Fig. 3). Below a water depth of $8-10 \mathrm{~m}$ most of the rock surfaces are covered by thick carpets of the chimneys of $P$. ciliata and the tubes of other polychaetes (except for Cretaceous flint and occasional occurrences of Pleistocene granite or quartzite boulders). In several channels north of the dune deeper patches of Mytilus edulis also occur. In these instances Echinus esculentus avoids the Mytilus colonies and keeps to the P. ciliata carpet. The Polydora carpet reaches a thickness of $0.5-1 \mathrm{~cm}$ and forms an excellent hiding place for all sorts of epibenthic organisms such as amphipods. Though maximal development of $P$. ciliata has been observed on the flat bottoms of Cretaceous chalk (Fig, 4), other rock types like Lower Triassic sandstone and Middle Triassic marls and limestones are also covered by thick carpets (Fig. 5). It should be noted, however, that the Triassic sandstones and marls reach carbonate concentrations of 20-30\%, which would allow chemical boring, the most probable boring mechanism of $P$. ciliata.

On all previously mentioned substrates, Echinus esculentus grazes very rapidly and efficiently, creating large clean areas bare of any Polydora ciliata chimneys.

Though the clean white chalk surfaces grazed by E. esculentus are much more conspicuous under water, the foraging activity is the same on the dark sandstones and marls of the Triassic (Fig. 4 and 5). The grazed areas seldom exceed $400-800 \mathrm{~cm}^{2}$, i.e. approx. 4-8 times the body size of E. esculentus. The size of these areas is related to 


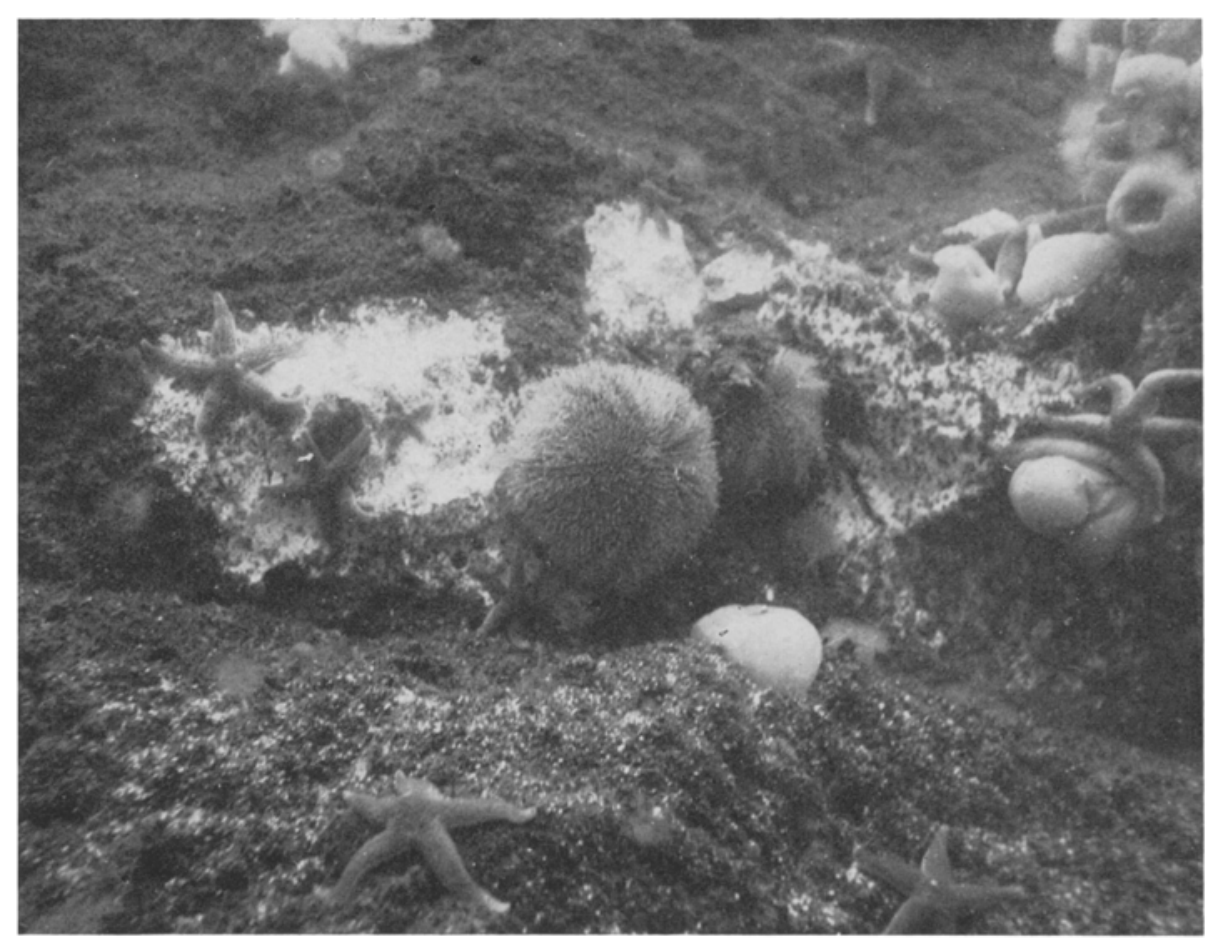

Fig. 4: Two individuals of Echinus esculentus graze on a bank of massive chalk (Cretaceous). The left individual has a double meandering pattern (see Fig. 6). The area cleaned by the second one indicates remopulation of the formerly cleaned regions by Polydora ciliata. (Photograph taken at $10-12 \mathrm{~m}$ water depth)

the population density of $P$. ciliata and $E$. esculentus respectively. Areas where 5-7 specimens $/ \mathrm{m}^{2}$ have been counted exhibit cleaned areas of only $200-300 \mathrm{~cm}^{2}$ while at places where 1 specimen $/ \mathrm{m}^{2}$ occurs, the browsed area reaches up to $800 \mathrm{~cm}^{2}$. Thus approximately $10-25 \%$ of the rodk surface is cleaned. Our aquarium observations demonstrate that in periods in which $E$. esculentus is not feeding it is wandering about and may thus control areas larger than those needed for food supply.

Rocky ridges and uneven ground apparently favour denser populations. The browsed zones are irregularly shaped (Fig. 4) and indicate meandering grazing behaviour. Generally the width of the browsed area corresponds to the sea-urchin's diameter while the length reaches several times the animal's size. Since the gnawing apparatus is much smaller, Echinus esculentus advances in a meandering path (Fig. 6).

After cleaning the rock surface from the Polydora ciliata chimneys, Echinus esculentus removes the top layer of the whole previously cleaned surface by biting off small pieces of rock. It thus gradually reaches the bottom of the $P$. ciliata holes and eats the worm itself. Since $P$. ciliata bores to a maximum depth of $1.5 \mathrm{~cm}$ and the main population is situated at 0.8 to $1.2 \mathrm{~cm}, E$. esculentus thus gradually erodes $\mathrm{ca} .1 \mathrm{~cm}$ of rock. 


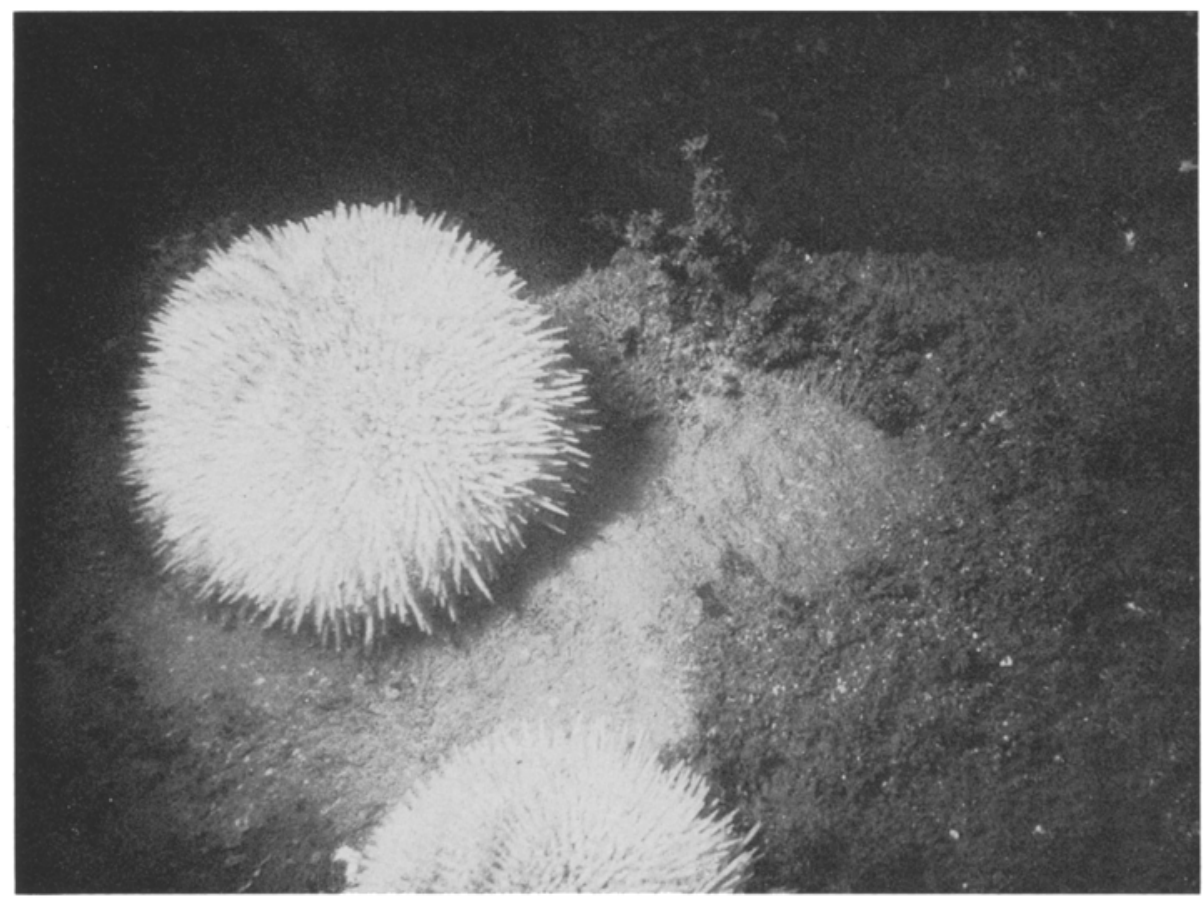

Fig. 5: Two individuals of Echinus esculentus graze on Triassic sandstone at $10 \mathrm{~m}$ water depth SW of Helgoland. The border between the cleaned area and the intact Polydora ciliata carpet is clearly visible at the upper right end of the browsed area

Only the few worms which have settled in the deepest holes ecape and within a few days construct new chimneys. Later the cleaned rock surface is repopulated by larvae, which settle preferentially close to the survivors, creating a patchy appearance on the rock.

Another type of biodeterioration has been observed mainly in the case of clearly layered Triassic marls and limestone but also on vertical cliffs of homogeneous rock. Echinus esculentus was advancing very rapidly scraping a deep V-shaped furrow of $1-2 \mathrm{~cm}$ width and $1 \mathrm{~cm}$ depth (Fig. $6 \mathrm{~b}$ ). The furrow clearly matches the outer profile of the gnawing apparatus.

The progress of erosion due to Echinus esculentus was estimated by the observation of flint concretions which are gradually dissected from the surrounding Cretaceous chalk by (1) the boring activity of Polydora ciliata and (2) subsequent grazing of Echinus esculentus in several sequences. The flint concretions in late stages are so fragile that heavy winter storms will break them off. We have observed concretions protruding $10-20 \mathrm{~cm}$ from the surrounding bottom, with $E$. esculentus gnawing on the thin bottle neck. Mollusc bore-holes, which in the soft Cretaceous chalk and Triassic marls reach depths of $5-10 \mathrm{~cm}$, are frequently eroded to the lowermost level indicating very fast and efficient deepening of the whole surface area by E. esculentus. In several cases the scrape-marks of the mollusc itself are still visible at the bottom of the 
hole thus indicating rather fast biodeterioration of the surroundings. Another possibility for estimating the speed of biodeterioration is to collect the frequently occurring faecal pellet heaps of E. esculentus.

Several of the heaps have been collected under water by suction pump and determined as between 3 and $5 \mathrm{~g}$ dry weight. In other cases the meandering behaviour of E. esculentus is expressed by scattered pellets on the browsing area.

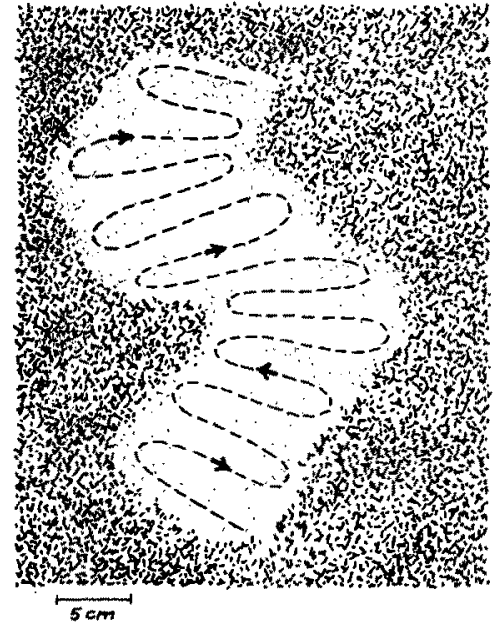

a

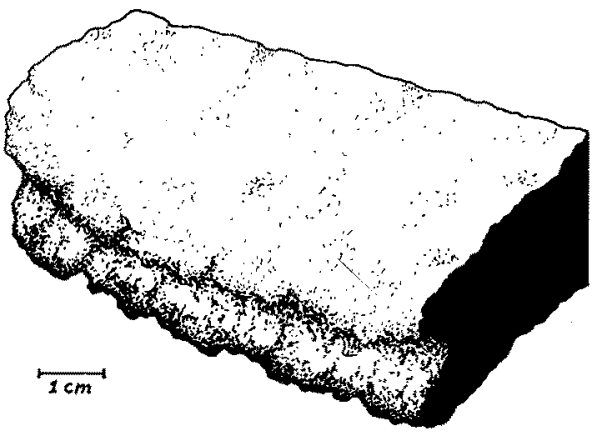

b

Fig. 6: Schematic drawing of different grazing behaviour of Echinus esculentus. a Zig-zag browsing zone (see Fig. 4) with indication of the meandering gnawing path of the animal on the previously cleaned area (see text). $b$ Deep furrow produced on a vertically exposed stratified rock. In these cases the width of the browsed area is sometimes smaller than the mouth opening

Observations in the field and in the aquarium indicate that surfaces cleaned by Echinus esculentus are overgrown very quickly (within 3-4 days) by algae and other organisms. Since it takes a longer time for Polydora ciliata to resettle and reconstruct its chimneys we were able to separate several stages of repopulation of the grazed areas. Although $E$. esculentus while browsing forms permanent relief differences of more than $2 \mathrm{~cm}$ it does not create burrows as hiding places like other echinoderms (e. g. Paracentrotus lividus).

\section{Aquarium observations}

Underwater observations of grazing behaviour, feeding activity and deterioration rates were supplemented by some experiments with Echinus esculentus and Psammechinus miliaris in the laboratory. Specimens of the various rock types of Helgoland covered by Polydora ciliata carpets and in some cases by encrusting algae and Bryozoa were placed in aquaria. Some specimens of E. esculentus and $P$. miliaris were added. 
Table 1

Daily production of pellets and detritus expressed as dry weights after treatment with $\mathrm{H}_{2} \mathrm{O}_{2}$ and dry weights of pellet heaps of uncertain age collected in the field

\begin{tabular}{|lcccc|}
\hline Species & Time & Sandstone & Limestone & Chalk \\
\hline Echinus esculentus & $24 \mathrm{~h}$ & $3.5 \mathrm{~g}$ & - & $3.9 \mathrm{~g}$ \\
Echinus esculentus & 7.* & $3.7 \mathrm{~g}$ & $4.8 \mathrm{~g}$ & $5.4 \mathrm{~g}$ \\
Psammechinus miliaris & $24 \mathrm{~b}$ & $3.2 \mathrm{~g}$ & - & $4.2 \mathrm{~g}$ \\
Psammechinus miliaris & 5 days & - & - & $18.5 \mathrm{~g}$ \\
$*$ collected in the field by suction pump. & & & \\
\hline
\end{tabular}

After a period of adaptation, both animals were wandering in the tank in irregular patterns, as observed also in the field. Echinus esculentus started feeding by gnawing a trail of $30 \mathrm{~cm}$ length and $2-3 \mathrm{~cm}$ width on Cretaceous chalk. It was observed that $E$. esculentus left its trail several times and returned later to the same place to continue its grazing on the cleaned surface (Fig. 7). In other cases E. esculentus also produced the deep furrows described previously (Fig. 6). The daily production of pellets was collected, treated with $\mathrm{H}_{2} \mathrm{O}_{2}$ to destroy organic matter, and the dry weight of the pellets was then determined. Both $E$. esculentus and $P$. miliaris were feeding in

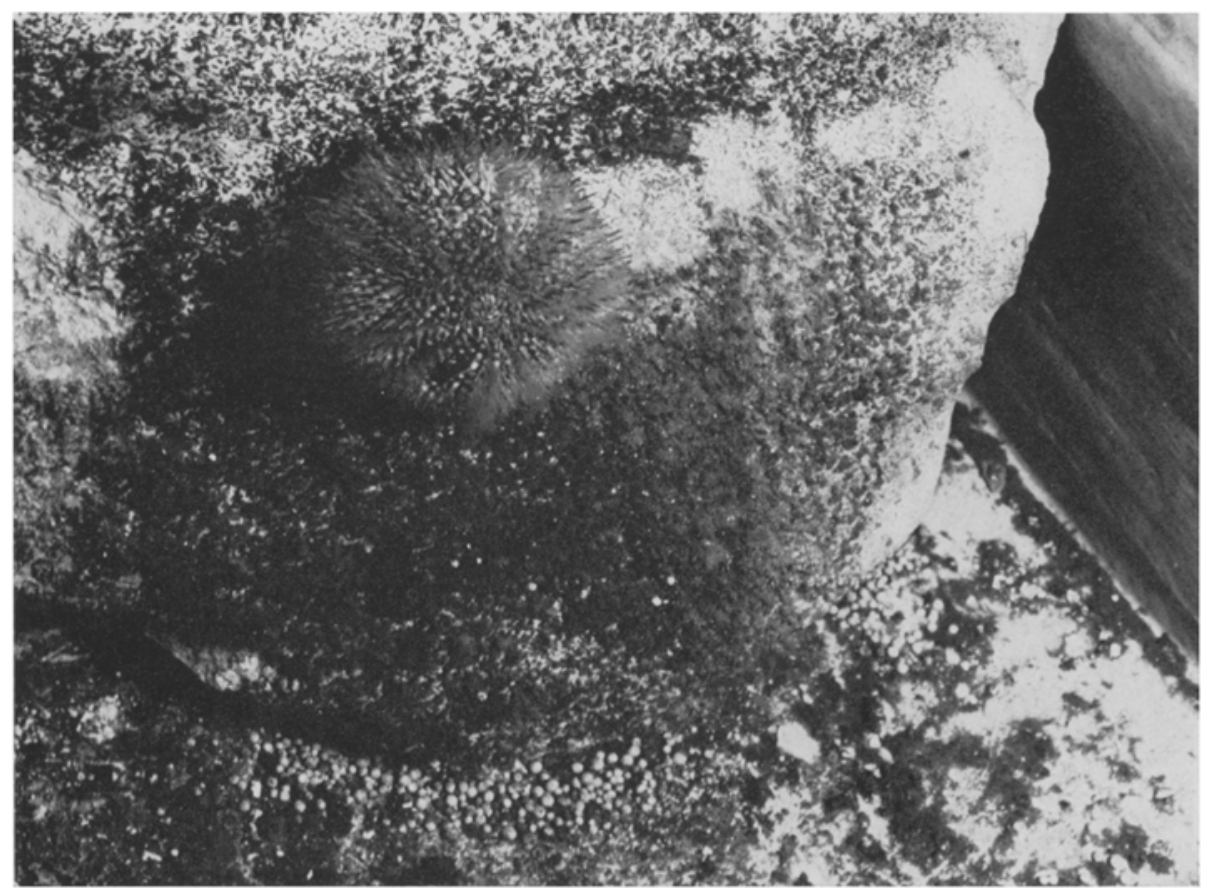

Fig. 7: Aquarium photo of Echinus esculentus grazing on Cretaceous chalk. The faecal pellets at the bottom represent quantitatively the eroded rock portion 
the aquarium on all rock types offered. It seems, that preference was given to the soft Cretaceous chalk. Several of the bite marks of E. esculentus and P. miliaris were photographed.

In contrast to Echinus esculentus, Psammechinus miliaris after some wandering settled in one spot and started feeding by creating a larger hole at one single location (Fig. 10). Since we did not want to disturb the animal, pellets were collected only after 5 days of feeding (Table 1 ). Within 5 days one specimen of $P$. miliaris created a hole of $25 \mathrm{~cm}^{3}$ volume. During the investigation time the animals also fed on sandstone and middle Triassic limestone. By dissecting some of the rocks exposed in the tanks it could be shown that E. esculentus gradually deepens its gnawing area until it reaches the lowermost borings of Polydora ciliata (Fig. 9).

We observed that the surviving Polydora ciliata reconstructed their chimneys within 3-4 days. At the same time, diatoms and other algae were repopulating the cleaned surfaces. After 4 days it was almost impossible in the case of the former Poly-

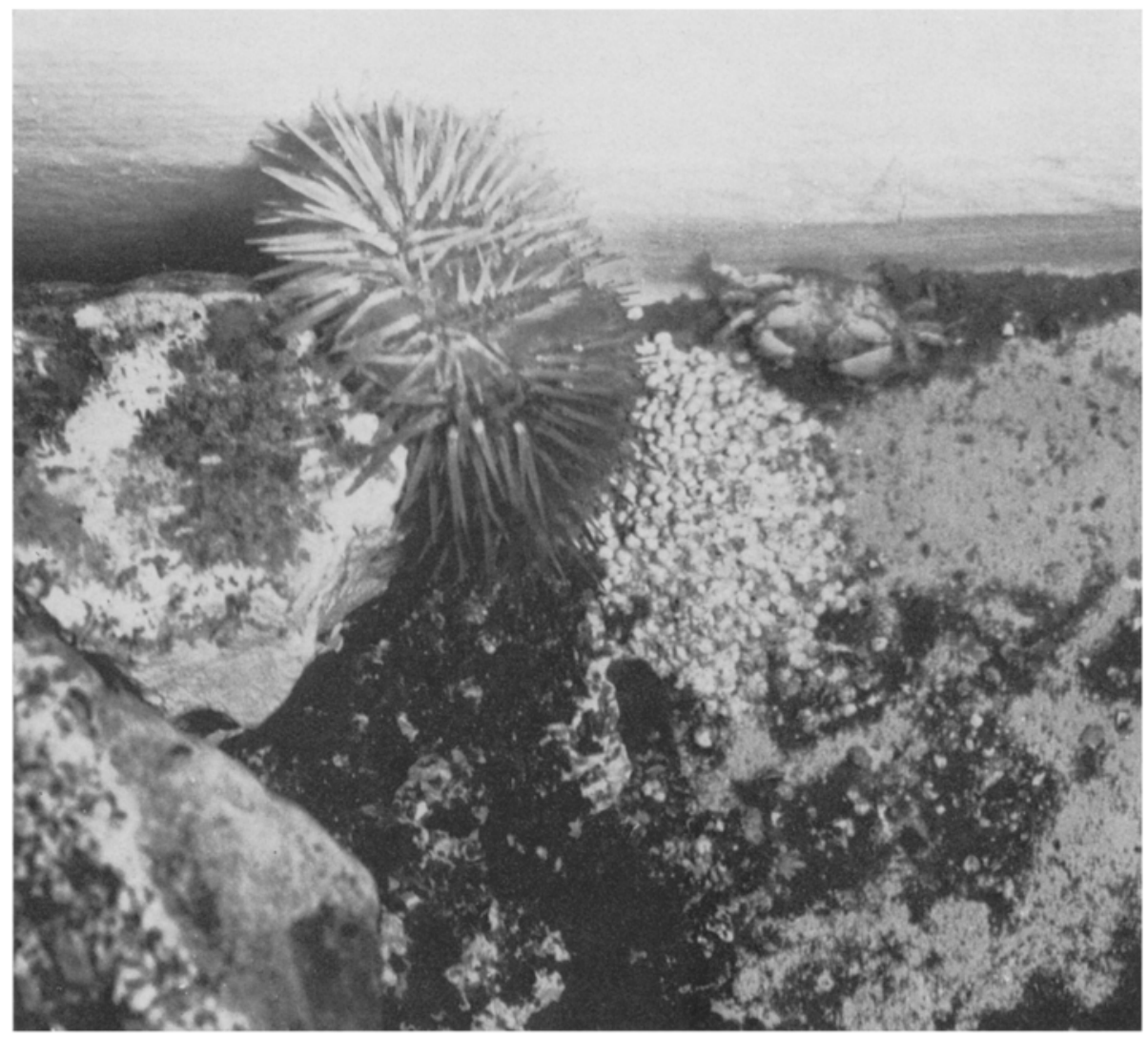

Fig. 8: After looking for a convenient place Psammechinus miliaris, in constrast to Echinus esculentus (Fig. 9), settles on a single place and feeds on Polydora ciliata. The pellet heap shown in this photograph yielded $18 \mathrm{~g}$ eroded chalk 

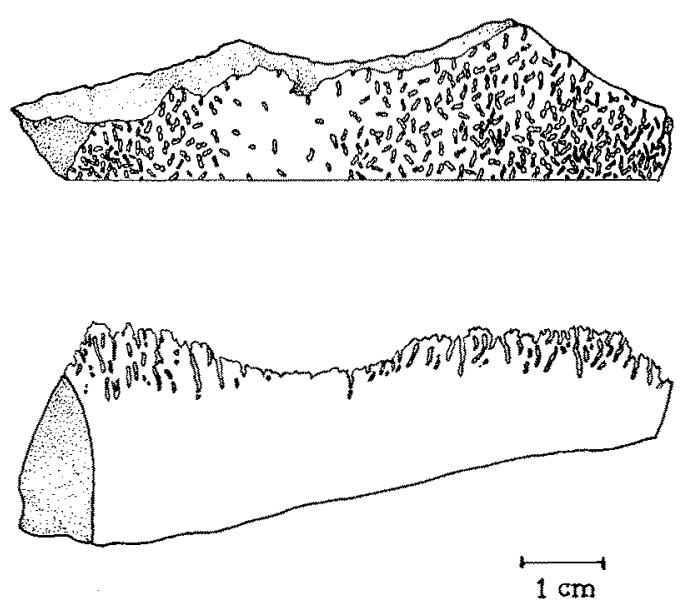

Fig. 9: Surface view and cross-section of the browsing path of Echinus esculentus. The browsed area exposes decreasing numbers of bore-holes. In the cross-section it can be seen that

E. esculentus is reading almost all worms, leaving intact only extremely deep burrows

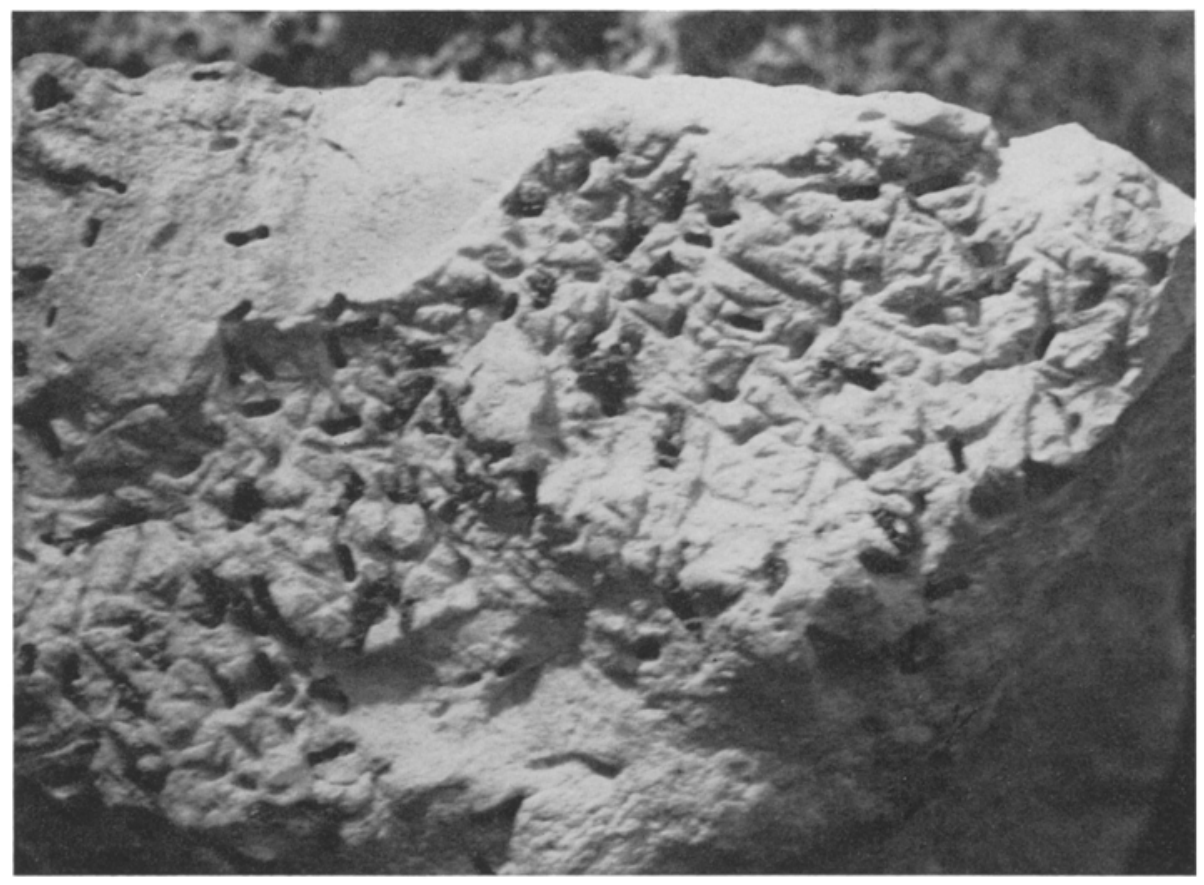

Fig. 10: Gnawing pattern of Echinus esculentus on chalk settled by Polydora ciliata. The stars are not clearly visible; a few isolated and deep furrows indicate the softness of the rock and the aim of the animal to reach the worm hidden inside the rodk 
dora carpets to identify the gnawing area, because the bite marks of Echinus esculentus on rocks inhabited by $P$. ciliata are very indistinct (Fig. 10). Generally it was very difficult, if not impossible, to distinguish between the bite marks of $E$. esculentus and $P$. miliaris. This is due to the fact, that the traces correspond less to the species or size of the animal than to the substrate and the type of food the animal was looking for.

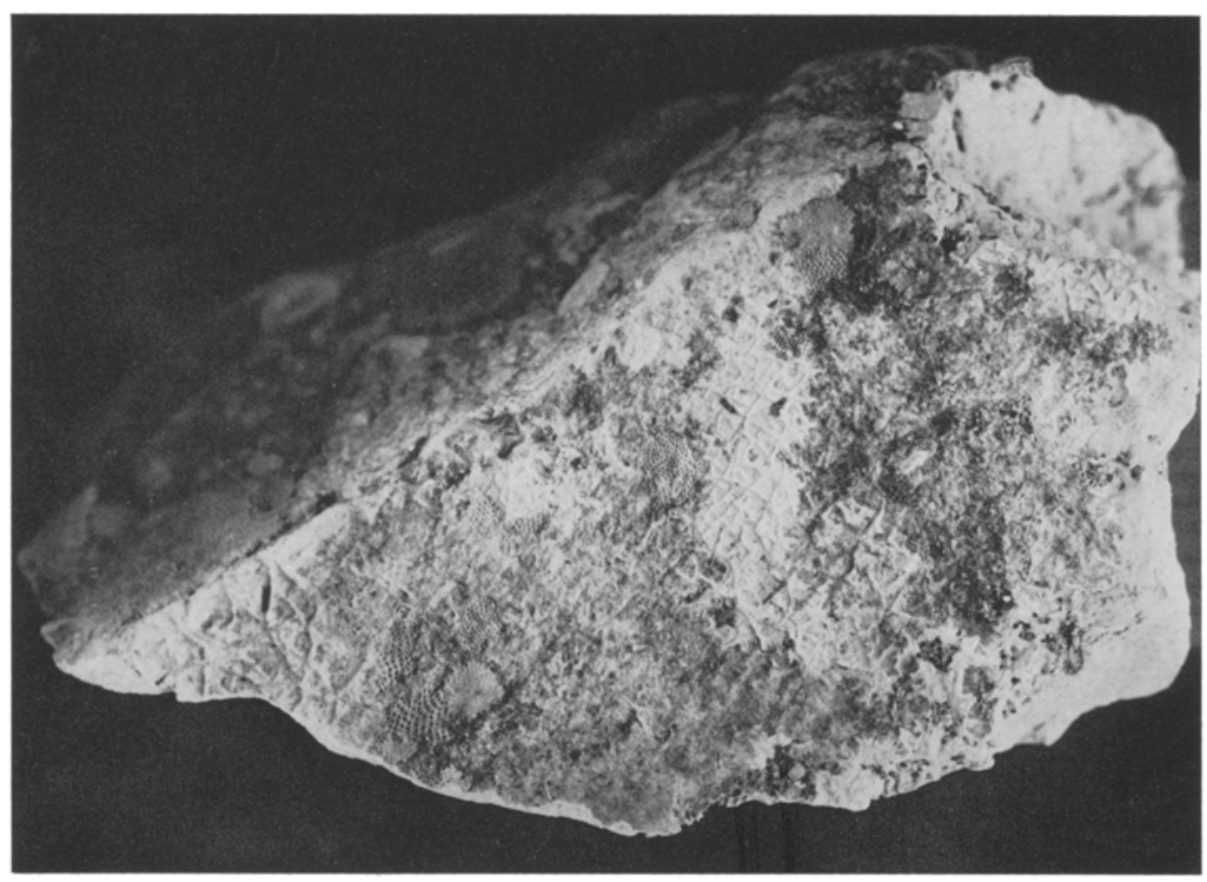

Fig. 11: Gnawing pattern of Psammechinus miliaris on Cretaceous chalk covered with a surface film of algae and bryozoans. In contrast to Figure 10 the animal is only browsing on the surface film. It does not need to get deeper into the rock. Therefore the ideal and typical star shaped gnawing pattern is developed. At the upper right (not in focus) a cavity is visible, which has been produced by $P$. miliaris in a period of 5 days

In soft chalk populated by Polydora ciliata, the surface is very rough, and the bite marks are interrupted by the Polydora holes. In addition the sea-urchin is trying to penetrate very deep into the rock to reach the worm itself. Since Echinus esculentus cannot reach $P$. ciliata at the first try, it has to bite several times in the same vicinity. The result is a criss-cross pattern of longer or shorter bite marks which do not exhibit the typical star form (Fig. 10). In cases where soft chalk or sandstone is covered by a film of algae or Bryozoa without $P$. ciliata borings, the sea-urchin feeds only at the surface, thus creating large stars (Fig. 11). In case of very hard substrates, such as flint covered with red algae, the stars generally are smaller than on soft subtrates. 


\section{DISCUSSION}

From underwater observations and aquarium experiments we conclude that at Helgoland a close relationship exists between the distribution of Polydora ciliata and Echinus esculentus. $P$. ciliata bores the rock surfaces beginning with the intertidal zone and increases in numbers and importance with increasing depth, attaining its maximum between 8 and $20 \mathrm{~m}$. The same is true for the population of E. esculentus at Helgoland. In contrast to $P$. ciliata, E. esculentus very rarely occurs in the intertidal zone.

Echinus esculentus grazes almost exclusively on the Polydora carpets and takes its main food not from biodetritus and animals living between the chimneys but by feeding on the worm itself. To reach the worm, E. esculentus has to scrape away between 0.5 and $1.2 \mathrm{~cm}$ of solid rock. Therefore at Helgoland E. esculentus differs completely in its feeding behaviour and population density from the populations recorded by Forster $(1958,1959)$.

FORSTER reported 1 animal/4-5 $\mathrm{m}^{2}$, while at Helgoland between 1 and 7 animals/ $\mathrm{m}^{2}$ occur. The cleaned surface areas in Forster's report vary between 2500 and $5000 \mathrm{~m}^{2}$. The cleaned surfaces at Helgoland are smaller by one order of magnitude, they range from $200-800 \mathrm{~m}^{2}$. This is due to the fact, that E. esculentus in the region investigated by Forster $(1958,1959)$ was feeding mainly on algal films on the rodky surface, while at Helgoland it penetrates $1 \mathrm{~cm}$ and more into the rock to feed on $P$. ciliata. Thus population density and eroding activity are much more accentuated in the Helgoland area.

Regarding the biodeterioration activity of the interacting populations of Polydora ciliata and Echinus esculentus at Helgoland it seems worthwhile to attempt an estimate and comparison of erosion by these animals and other factors at Helgoland.

Aside from destruction in the immediate intertidal zone in the past (cliffs at 13 and $20 \mathrm{~m}$ water depth), and today (present cliff), the sea is contributing to weathering by wave action, subsolution and tidal currents. It has been observed that after heavy storms big boulders have been broken off the submarine Cretaceous cliffs, exposing clean white surfaces. In addition, tidal channels with white clean surfaces polished by the sand moving through the channels are frequently observed (Fig. 2).

At these places the water movement is too strong for the settlement of Polydora ciliata (see p. 5). The frequently exposed strata of gypsum in the Lower and Middle Triassic are dissolved slowly by the water. The gypsum strata also remain unpopulated by epilithic or endolithic organisms.

Boring molluscs occur quite frequently at Helgoland and perforate all rock types. As mentioned before, these do not contribute as much to the biodeterioration process as E. esculentus since the eroding activity of the sea-urchin can be measured by the frequency of empty mollusc bore-holes which are reduced to depths below $1 \mathrm{~cm}$.

As for the Polydora ciliata-Echinus esculentus community we have two possibilities for estimating its contribution to biodeterioration.

(1) The toral area of the uplifted geologic complex of Helgoland exposing mainly rocky bottoms approaches $50 \mathrm{~km}^{2} .15-20 \mathrm{~km}^{2}$ of this area are more or less densely populated by the $P$. ciliata- $E$. esculentus community. The population density of $E$. esculentus is between $1-7 / \mathrm{m}^{2}$. If we assume, on the basis of our observations, that $E$. 
esculentus erodes approximately $1 \mathrm{~cm}$ of the rock surface on $200-800 \mathrm{~cm}^{2}$ within a few days and that by wandering it covers $1 \mathrm{~m}^{2}$ in a few months, we can deduce that $E$. esculentus removes at least a 1-cm-layer of rock annually. $P$. ciliata has been shown to populate densely a freshly eroded surface within 2 months (HEMPEL 1957). Therefore it is even possible that at certain places biodeterioration by E. esculentus exceeds by far $1 \mathrm{~cm} /$ annum. Compared to other reports on bioerosion, this is a relatively large amount.

The Helgoland area was re-submersed by the sea approximately 6000 years ago. According to our knowledge the whole area has changed its relief considerably in historical time. This must at least partially be due to the $P$. ciliata-E. esculentus community. Fluctuations in population may have reduced the extremely high figures we calculated.

(2) On the basis of daily food uptake as reported in our laboratory experiments we can also calculate the volume of rock destroyed by one specimen of E. esculentus. During its feeding periods, E. esculentus was passing 3-4 $\mathrm{g}$ of rock/day through its intestinal tract (Table 1). If we assume that the feeding periods make up at least $1 / 4$ of the year, an erosion rate of $500 \mathrm{~g}$ eroded rock material/specimen/annum is reached. On the basis of an average population density of $3 / \mathrm{m}^{2}$ on the Helgoland rocks at the investigated depth the total $E$. esculentus population may attain $6 \times 10^{7}$ individuals. This would lead us to the sum of 30000 tons of rock eroded annually. If we assume the density of that part of the rock already bored by $P$. ciliata being around 1.0, we reach the same value for biodeterioration as in our previous calculation, i. e. $1 \mathrm{~cm} /$ annum or $1 \mathrm{~m} /$ hundred years.

We are aware of the fact that mass calculations with fluctuating populations including extrapolations from small areas analysed are rather speculative. It is noteworthy, though, that both approaches with different sets of data lead to the same order of magnitude for the total biodeterioration rate.

These rapid erosion rates can only be reached because the rocks of Helgoland are either carbonate rocks or soft calcareous sandstones and marls. In other cases McCLEAN (1967) and STEPHENSON (1961) stress the importance of the rocky substrate and the boring activity of endolithic blue-green algae for subsequent bioerosion by snails and fish. These organisms feed in a manner which is the cause of considerable erosion. MOORE (1966) and REESE (1966) summarize boring activities also for other sea-urchins (like Diadema, or Strongylocentrotus). These mainly bore to produce a hiding place and not to reach their prey. An ecological survey and estimates of bioerosion by seaurchins have also been given by KEMPF (1962).

Bioerosion by lithophagic organisms in general has been frequently described for tropical regions (MCCLEAN 1967, 1972; NeumanN 1966, 1968). The terms bioerosion (NEUMANN 1966) and biodeterioration (e. g. Krumbein 1972) have been proposed for this kind of eroding activity of various organisms. Most of the calculations and estimates of erosion rates have been reported for subtropical or tropical intertidal environments (NEUMANN 1968).

SOUTHWARD (1964) reports erosion rates by limpets reaching $1.5 \mathrm{~cm} / 100$ years. JEHU (1918) quotes erosion rates by boring molluses as high as $1 \mathrm{~cm} /$ annum. NoRTH (1954) and MCCLEAN (1967) give data for Littorina and other gastropods at the Cali- 
fornian and Barbados coasts which reach a maximum rate of $1 \mathrm{~cm} / 16$ years in the intertidal zone. They have used the same method of measuring the dry weight of the faecal pellets produced. In contrast to our work both of these authors included organic matter in their dry weight estimates. SCHNEIDER (1973) refers also to snails grazing on the rocky intertidal zone of the Adriatic coast. Furthermore he stresses the importance of endolithic algae in coastal erosion. Stephenson (1961) studies fish browsing on endolithic algae in beachrock at Heron Island.

Neumann (1966) has calculated bioerosion rates brought about mainly by the boring sponge Cliona lampa at Bermuda. He gives figures of $1 \mathrm{~m} / 110-180$ years which correspond to our calculated erosion rates. At Helgoland we have also observed Cliona celata as a rock borer. For two reasons, C. celata is not as important an eroding factor at Helgoland: (1) It is less frequent by at least one order of magnitude than Polydora ciliata as can be shown by statistical analyses of bored rocks thrown up on the beach of the Helgoland dune. (2) In general Cliona celata occurs together with a cover of encrusting coralline algae such as Lithothamnion. E. esculentus at Helgoland prefers rock surfaces without calcareous red algae and has its maximum distribution in regions and on rocks bare of Cliona celata. Also Fonster (1959) observes that $E$. esculentus does not feed on calcareous algae. Most of the biodeterioration data in the marine environment have thus been collected in tropical and subtropical intertidal areas. For several reasons coastal erosion and cliff erosion in the tropics should be faster in general than bioerosion of horizontal sublittoral surfaces in colder regions. It is thus extremely interesting that such high erosion rates as $1 \mathrm{~m} / 100$ years have been calculated for the cold waters of Helgoland at water depths between 8 and $20 \mathrm{~m}$.

The coincidence of underwater outcrops of soft sandstones, marls and limestones with the combined activity of the Polydora ciliata-Echinus esculentus community therefore gives an interesting and exceptional example of bioerosion below the low tide level. Since $E$. esculentus seems to prevent major growth of Laminaria beneath a certain light level depending on water depth (Jones \& Karn 1967; KitchING \& EBLING 1961) it can be similarly concluded that the population of $P$. ciliata on the soft Helgoland rocks is favoured by its predator. Regarding the instability of the tectonically produced Helgoland structure (salt dome), its relatively recent origin (p. 2), its soft rocks and the unusually high biodeterioration rates recorded here, it is assumed that the whole ecosystem has no major longevity. The extremely rapid lowering of the rocky bottom in general and the subsequently increasing sediment cover will decrease the substrate area and the activity of this unique community. It is noteworthy in this context that the outer and deeper margins of the $P$. ciliata- $E$. esculentus community are exposing shifting frontiers as indicated by Polydora carpets covered with sand after heavy storms. The worms may survive for a while, but will be killed later by lack of oxygen and thus create black reducing zones due to rapid anaerobic decay and sulphide production. With different wind direction and velocities these zones may become uncovered again for some time and be populated by oxidizing microorganisms and new worm colonies. Later on the periods with major sediment cover will be prolonged and the total surface area of the bioerosion zone will gradually decrease.

The combined subaeric (KRUMBErN, in preparation) and submarine erosion of the 
Helgoland structure has made remarkable progress in historical time and can be derived from maps and ancient reports of underwater cliffs and rocks which were still visible in the last century at low tide and remain completely covered today. The $P$. ciliata-E. esculentus community is only one factor within this generalized picture of the process of destruction of the Helgoland structure.

\section{SUMMARY}

1. The Polydora ciliata-Echinus esculentus community of the rocky sublittoral of the island of Helgoland (North Sea) has been studied by SCUBA-diving methods and laboratory experiments.

2. The sublittoral zone of Helgoland at water depths between 8 and $20 \mathrm{~m}$ is settled mainly by the boring polychaete Polydora ciliata and associated organisms. $P$. ciliata bores all local types of rock, except Triassic gypsum beds and Cretaceous flint layers.

3. The main predator of $P$. ciliata is Echinus esculentus occurring in extremely high population densities ( $1-7$ specimens $\left./ \mathrm{m}^{2}\right)$.

4. E. esculentus cleans surface areas from $100-800 \mathrm{~cm}^{2}$ of $P$. ciliata chimneys and subsequently rasps off the rock itself until it reaches the worms in depths from $0.5-1.5 \mathrm{~cm}$.

5. At the location of vertical cliffs and well-stratified marls and limestones also deep furrows of up to $30 \mathrm{~cm}$ length and only $1.5-2.0 \mathrm{~cm}$ width are produced in the field and in laboratory experiments, within a few days.

6. The less frequently occurring sea-urchin Psammechinus miliaris, in contrast to $E$. esculentus, controls much smaller areas at a time and generally feeds on a surface area not larger than its body size.

7. Laboratory experiments and field measurements yielded erosion rates of up to $5 \mathrm{~cm}^{3}$ rock eroded/specimen/day for $E$. esculentus.

8. The combined activities of $P$. ciliata and $E$. esculentus lead to bioerosion rates (calculated from surface area cleaned and pellet weights) of at least $1 \mathrm{~cm} /$ annum as an overall estimate.

9. Extrapolations of the populations of E. esculentus at the Helgoland sublittoral area in 1973 reach figures of $2 \times 10^{7}$ to $1 \times 10^{8}$ animals with an annual production of approximately 30000 tons of rock detritus. This in relation to the surface area in question again yields bioerosion rates of $1 \mathrm{~cm} /$ annum.

Acknowledgements. The authors are indebted to the diving group of the Biologische Anstalt Helgoland supporting the field work. Thanks are extended to Dr. GREVE and the colleagues taking care of guest researchers at Helgoland. Part of this work was made possible by a grant of the Geologisch Instituut Groningen. I. Ferber of the Hebrew University, Jerusalem, was helpful in discussion of echinoderm ecology. Dr. von Hentig kindly revised the English version.

\section{LITERATURE CITED}

Forster, G. R., 1958. Underwater observations on the fauna of shallow rocky areas in the neighbourhood of Plymouth. J. mar. biol. Ass. U. K. 37, 473-482. 
- 1959. The ecology of Echinus esculentus L. Quantitative distribution and rate of feeding. J. mar. biol. Ass. U. K. 38, 361-367.

Hartung, W., 1970. Helgoland, merkwürdigste Insel der Nordsee. Veröff. naturf. Ges. Emden 105, 35-37.

Hempel, C., 1957. Über den Röhrenbau und die Nahrungsaufnahme einiger Spioniden (Polychaeta sedentaria) der deutschen Küsten. Helgoländer wiss. Meeresunters. 6, 100-135.

JEHU, T. J., 1918. Rock boring organisms as agents in coastal erosion. Scott. geogr. Mag. 34, $1-10$.

Jones, N. S. \& KaIN, J. M., 1967. Subtidal algal colonization following the removal of Echinus. Helgoländer wiss. Meeresunters. 15, 460-466.

KempF, M., 1962. Recherches d'écologie comparée sur Paracentrotus lividus et Arbacia lixula (L.). Rec. Trav. Stn mar. Endoûme 25 (39), 47-116.

Krtching, J. A. \& Ebling, F. J,, 1961. The ecology of Lough Ine. II. The control of algae by Paracentrotus lividus (Echinoidea). J. Anim. Ecol. 30, 373-384.

Krumbein, W. E., 1972. Rôle des microorganismes dans la génèse la diagénèse et la dégradation des roches en place. Revue Ecol. Biol. Sol. 9, 283-319.

- Verwitterung, Abtragung und Küstenschutz auf der Insel Helgoland. Abh. naturw. Ver. Hamburg (im Druck).

LüNING, K., 1970. Tauchuntersuchungen zur Vertikalverteilung der sublitoralen Helgoländer Algenvegetation. Helgoländer wiss. Meeresunters. 21, 271-291.

MCClEAN, R. F., 1967. Measurements of beachrock erosion by some tropical marine gastropods. Bull. mar. Sci. 17, 551-561.

- 1972. Nomenclature for rock-destroying organisms. Nature, Lond., 240, 490.

Moore, H. B., 1966. Ecology of Echinoids. In: Physiology of Echinodermata. Ed. by E. A. Boolootian. Wiley-Interscience, New York, 73-85.

Neumann, A. C., 1966. Observations on coastal erosion in Bermuda and measurements of the boring rate of the sponge, Cliona lampa. Limnol. Oceanogr. 11, 92-108.

- 1970. Biological erosion of limestone coasts. In: Encyclopedia of geomorphology. Ed. by R. W. Fairbridge. Reinhold, New York, 75-81.

NorTh, W. J., 1954. Size distribution, erosive activities, and gross metabolic efficiency of the marine intertidal snails, Littorina planaxis and L. scutulata. Biol. Bull. mar. biol. Lab., Woods Hole 106, 185-197.

Orton, J. H., 1930. On the occurence of Echinus esculentus on the foreshore in the British Isles. J. mar. biol. Ass. U. K. 16, 289-296.

PratJe, O., 1923. Geologischer Führer für Helgoland und die umliegenden Meeresgründe. Bornträger, Berlin, $128 \mathrm{pp}$.

REESE, E. R., 1966. The complex behaviour of echinoderms. In: Physiology of Echinodermata. Ed. by R. A. Boolootian. Wiley-Interscience, New York, 157-218.

SCHNEIDER, J., 1973. Biologische und anorganische Faktoren beim Abbau einer Kalkküste. Habilitationsschr. Göttingen, 329 pp. (unveröff.).

SOUTHWARD, A. J., 1962. Limpet grazing and the control of vegetation on rocky shores. In: Grazing in terrestrial and marine environments. Ed. by D. J. Crisp. Blackwell, Oxford, 265-273.

Stephenson, W. \& Searles, R. B., 1961. Experimental studies on the ecology of intertidal environments at Heron Island. Aust. J. mar. Freshwater Res. 12, 164-176.

First author's address: Prof. Dr. W. E. Krumbern

Universität Oldenburg

Fadbereich IV

29 Oldenburg

Postfach 943

Federal Republic of Germany 